Biogeosciences Discuss., 7, 3735-3763, 2010

www.biogeosciences-discuss.net/7/3735/2010/

doi:10.5194/bgd-7-3735-2010

(C) Author(s) 2010. CC Attribution 3.0 License.

Temperate woodland carbon cycle

K. Fenn et al.

\title{
Comprehensive description of the carbon cycle of an ancient temperate broadleaved woodland
}

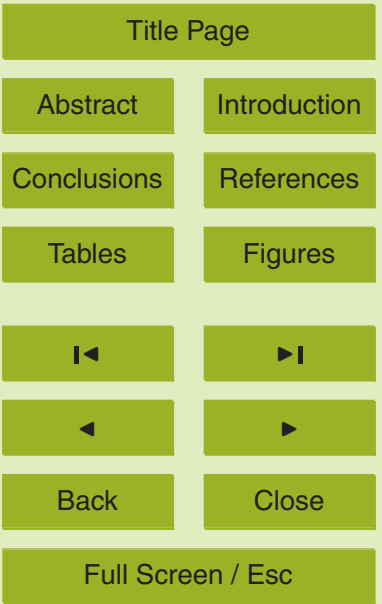

Received: 25 March 2010 - Accepted: 8 April 2010 - Published: 21 May 2010

Printer-friendly Version

Published by Copernicus Publications on behalf of the European Geosciences Union. 


\section{Abstract}

There exist very few comprehensive descriptions of the productivity and carbon cycling of forest ecosystems. Here we present a description of the components of annual Net Primary Productivity (NPP), Gross Primary Productivity (GPP), autotrophic 5 and heterotrophic respiration, and ecosystem respiration $\left(R_{\mathrm{ECO}}\right)$ for a temperate mixed deciduous woodland at Wytham Woods in southern Britain, calculated using "bottomup" biometric and chamber measurements (leaf and wood production and soil and stem respiration). These are compared with estimates of these parameters from eddy-covariance measurements made at the same site. NPP was estimated as $107.0 \pm 0.8 \mathrm{MgCha}^{-1} \mathrm{yr}^{-1}$, and GPP as $20.3+1.0 \mathrm{MgCha}^{-1} \mathrm{yr}^{-1}$, a value which closely matched to eddy covariance-derived GPP value of $21.1 \mathrm{MgCha}^{-1} \mathrm{yr}^{-1}$. Annual $R_{\mathrm{ECO}}$ was calculated as $18.9 \pm 1.7 \mathrm{MgCha}^{-1} \mathrm{yr}^{-1}$, close to the eddy covariance value of $19.8 \mathrm{MgCha}^{-1} \mathrm{yr}^{-1}$; the seasonal cycle of biometric and eddy covariance $R_{\mathrm{ECO}}$ estimates also closely matched. The consistency between eddy covariance and biometric measurements substantially strengthens the confidence we attach to each as alternative indicators of site carbon dynamics, and permits an integrated perspective of the ecosystem carbon cycle. $37 \%$ of NPP was allocated below ground, and the ecosystem carbon use efficiency (CUE, = NPP/GPP) calculated to be $0.35 \pm 0.05$, lower than reported for many temperate broadleaved sites.

\section{Introduction}

Forest carbon cycles are a topic of immense interest in the context of global environmental change, but to date there have been few comprehensive descriptions of the production, allocation and cycling of carbon within particular forest systems. To determine an ecosystem's productivity and respiration, its flux of $\mathrm{CO}_{2}$ can be measured directly above canopy via eddy covariance, or as a summation of the individual cycle components; the individual production and respiration terms. Whilst the eddy
BGD

7, 3735-3763, 2010

\section{Temperate woodland carbon cycle}

K. Fenn et al.

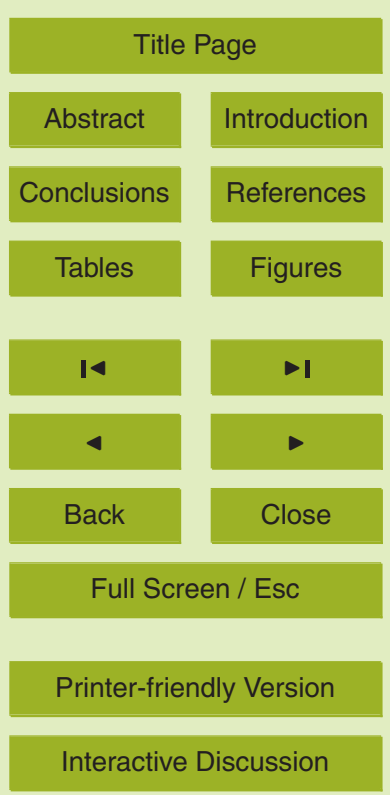


covariance method has been successfully deployed in many ecosystems (Falge et al., 2002), providing continuous monitoring of the fluxes to and from the system, many sites are unsuitable for this method, having insufficient fetch or uneven topography that render micrometeorological approaches problematic. In such sites the measurement of 5 individual components, such as stem growth, can be used, (with appropriate estimates for unmeasured variables if necessary) to quantify ecosystem productivity and respiration. Measuring individual components is also complimentary to the eddy covariance approach as it provides a far greater understanding of the system beyond total values of Gross Primary Productivity (GPP) and ecosystem respiration $\left(R_{\mathrm{ECO}}\right)$, allowing criti10 cal processes and their sensitivities to be identified. This is important for understanding how changes in factors such as climate, species composition and management may influence carbon dynamics at different sites, and how carbon dynamics may alter with changes in these factors.

Each method for measuring the contribution of individual components has associated errors and inaccuracies, in both the collection of data, or in scaling up to ecosystem scale. By comparing the magnitude and seasonality of the fluxes as measured by either method, potential sources of error can be identified, and to some extent quantified.

In this study we present monthly and annual data for the major components of productivity and respiration at a site of ancient semi-natural deciduous woodland in southern Britain. For each component an appropriate frequency of measurement was chosen to enable production of monthly estimates of carbon uptake or release, and so determine the effect of this system's seasonality on its annual carbon cycle. The seasonal nature of deciduous forests, with periods of dormancy and growth generally coinciding with changes in temperature and photoperiod, results in seasonal variation in the uptake and release of $\mathrm{C}$ by individual carbon cycle components during the year. Eddy covariance data were collected over the same period and provide an independent data set on the seasonality and magnitude of whole-system $\mathrm{C}$ flux (companion paper by Thomas et al., 2010).
BGD

7, 3735-3763, 2010

\section{Temperate woodland carbon cycle}

K. Fenn et al.

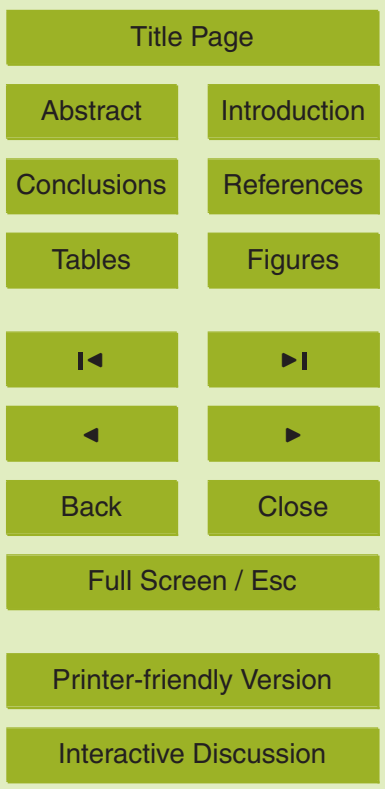


There have been very few comprehensive descriptions of forest carbon cycles, using both "bottom-up" biometric and flux chamber measurements and "top down" eddy covariance methods (Curtis et al., 2002; Ehman et al., 2002; Griffis et al., 2004; Malhi et al., 2009) and this is the one of the first, to our knowledge, which presents detailed bio5 metric measurements of productivity and respiration, and compares annual totals with eddy covariance data, for a temperate mixed deciduous forest site in Europe (Valentini et al., 1996). Our aims here are to:

(1) Produce monthly estimates of the main components of ecosystem productivity and respiration to determine their seasonality and comparative magnitude.

(2) Estimate annual total ecosystem net primary productivity and respiration and their partitioning between various components.

(3) Compare these biometric and chamber estimates of site productivity and respiration with independent eddy covariance measurements, and check for completeness in our description of the forest carbon cycle.

\section{Methods}

This paper draws on and integrates work described in companion papers (based on Fenn 2010; PhD Thesis), focussed on intensive measurements at this study site, over the period 2005-2008. These papers explore in detail our measurements of total and partitioned soil respiration, (Fenn et al., 2010), tree stem respiration and growth, and allocation of above ground primary productivity. The methods involved for these components will therefore not be covered in full detail here, but sufficient detail on methods and additional methods needed to fill in other $\mathrm{C}$ cycle components, and to scale up to plot level, are given.

\section{BGD}

7, 3735-3763, 2010

\section{Temperate woodland carbon cycle}
K. Fenn et al.

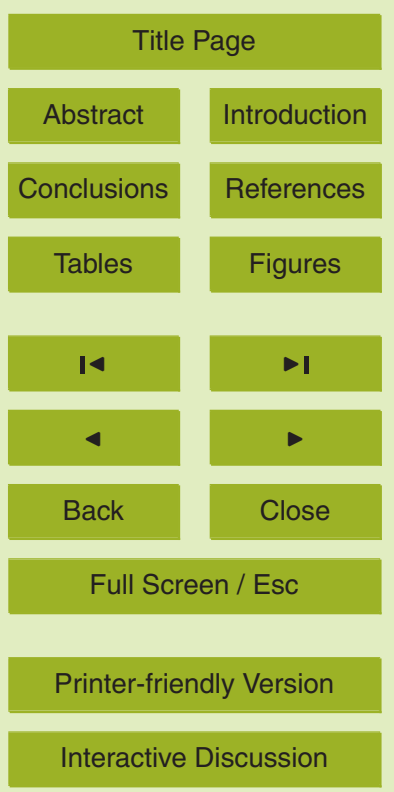




\subsection{Site description}

All measurements were conducted in a 1 ha plot in Wytham Woods, Oxfordshire, UK $\left(1^{\circ} 19^{\prime} \mathrm{W}, 51^{\circ} 46^{\prime} \mathrm{N}\right.$; UK National Grid: SP 46 08) (Kirby and Thomas, 2000). The site is divided into 25 subplots, $20 \mathrm{~m} \times 20 \mathrm{~m}$, used to structure the placement of multiple mea5 surement points for some methods. The site is ancient semi-natural woodland, UK National Vegetation Classification community W8 Fraxinus excelsior - Acer campestre Mercurialis perennis woodland (Hall et al., 2004). The term "ancient woodland" means that the site has had a continuity of tree cover though recorded history (since approximately 1600, Peterken and Game, 1984). It has however been managed throughout this periods, including by timber removal and the species composition has changed over time (Morecroft et al., 2008). Over approximately the last 40 years the plot and most of the surrounding area in the flux footprint have been subject to minimum intervention with no silvicultural management.

The majority of trees ( $>10 \mathrm{~cm}$ diameter at breast height, $\mathrm{dbh})$ in the study plot are 15 sycamore Acer pseudoplatanus L. (323; 70\%) and ash Fraxinus excelsior L. (80; 17\%), the remainder being pedunculate oak Quercus robur L. (24; 5\%), hawthorn Crataegus monogyna L., hazel Corylus avellana L., blackthorn Prunus spinosa L. and field maple Acer campestre $L$. The ground vegetation is predominantly dogs' mercury Mercuralis perennis $L$. with stinging nettle Urtica dioica $L$., bluebells Hyacinthoides non-scripta $L$. Chourad ex Rothm. in spring and pendulous sedge Carex pendula Huds.

The soil is mostly a stagni-vertic cambisol, derived from clay, with areas of arenihaplic luvisols and calcaric cambisols (FAO/UNESCO classification from Beard 1993). Meteorological data have been recorded on site since 1992 as part of the UK Environmental Change Network (ECN) monitoring programme (Morecroft et al., 1998). For the period 1993-2008 mean annual precipitation was $725.8 \mathrm{~mm}$, mean annual temperature was $10.1^{\circ} \mathrm{C}$, mean air temperature of the warmest month (from hourly mean temperatures) was $16.7^{\circ} \mathrm{C}$ for both July and August, and mean coolest month temperature (from hourly mean temperatures) was $4.4^{\circ} \mathrm{C}$ (December).

BGD

7, 3735-3763, 2010

Temperate woodland carbon cycle

K. Fenn et al.

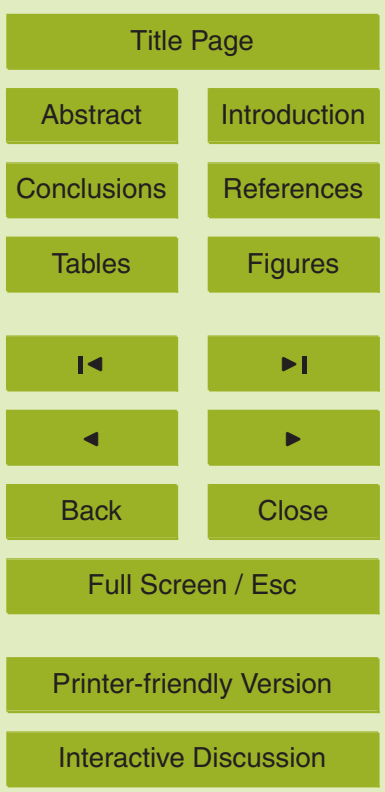

Interactive Discussion 


\subsection{Wood production}

Tree growth was measured for a subsample of trees (280 out of 466 ) over $10 \mathrm{~cm} \mathrm{dbh}$. Monthly measurements of dbh change were taken from dendrometer bands (adapted from Keeland and Young, 2005) using vernier gauge callipers to a precision of 0.5

$5 \mathrm{~mm}$ in circumference ( $<0.2 \mathrm{~mm}$ in diameter). Measurements started in 2006; the first measurements reported here were taken on 3 February 2007 and last on 12 December 2008. No measurements were made in January and February 2008 when growth rates were very low; December-March total growth was assumed to be evenly apportioned between January, February and March.

10 Dendrometer measurements were scaled up to estimates of tree aboveground dry woody biomass (ABW, kg) using species-specific allometric equations (Eqs. 1-3) for $A$. pseudoplatanus, $F$. excelsior and $Q$. robur, where $c$ is trunk circumference $(\mathrm{cm})$ at breast-height.

A. pseudoplatanus $\mathrm{ABW}=e^{(-5.644074+(2.5189 \cdot(\ln c)))}$

15 F. excelsior $\mathrm{ABW}=e^{(-5.308133+(2.4882 \cdot(\ln c)))}$

Q. robur $\mathrm{ABW}=e^{(-5.284602+(2.4682 \cdot(\ln c)))}$

These equations were calculated by Bunce (1968) for trees harvested at Meathop Wood, a site similar to Wytham in species composition. Mean coefficients from these three equations were used for the remaining species (contributing $8 \%$ of the individuals in the plot) which were almost all small trees.

$\mathrm{ABW}$ was converted to mass of carbon by taking the fractional carbon content of dry wood to be $0.469 \pm 0.008,0.491 \pm 0.005$ and $0.474 \pm 0.005 \mathrm{~g} \mathrm{C} \mathrm{g}^{-1} \mathrm{ABW}$ for A. pseudoplatanus, F. excelsior and $Q$. robur, respectively, from data obtained at Wytham (Butt et al., 2009), and the mean value of $0.477 \pm 0.003 \mathrm{~g} \mathrm{C} \mathrm{g}^{-1} \mathrm{ABW}$ for the remaining species. Mean biomass increment per tree of $A$. pseudoplatanus, F. excelsior, $Q$. robur, and the

BGD

7, 3735-3763, 2010

Temperate woodland carbon cycle

K. Fenn et al.

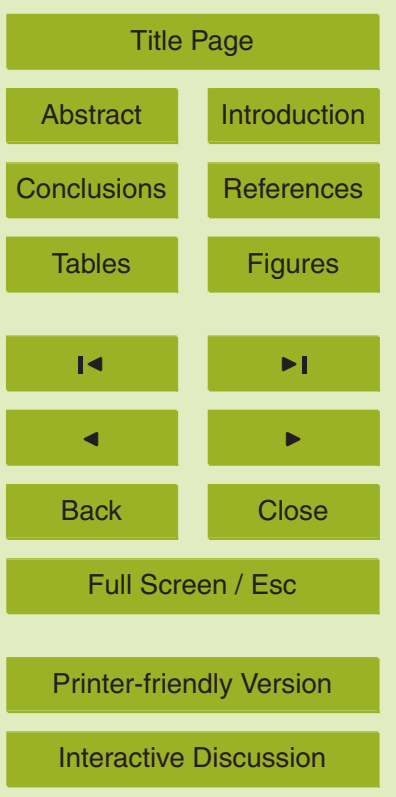


remaining species grouped together, was then calculated, and multiplied by the number of individuals of each species, to produce the plot-level estimate of annual wood production ( $\left.\mathrm{MgC} \mathrm{ha}^{-1} \mathrm{yr}^{-1}\right)$.

\subsection{Root production}

5 Fine root production (NPP fineroot $)$ was not directly measured, but rather estimated using a mass balance approach, where belowground $C$ input (root mortality and material carried down from the litter layer) is assumed equal to the belowground carbon outputs (SOM respiration, and dissolved organic $C$ in water, DOC), plus any change in soil $C$ stocks:

$\mathrm{NPP}_{\text {fineroot }}+\left(\mathrm{NPP}_{\text {litter }} \cdot F_{\mathrm{LITTER}}\right)+\left(M_{\mathrm{AG}} \cdot F_{\mathrm{CWD}}\right)+M_{\mathrm{BG}}=R_{\mathrm{SOM}}+\left(F_{\mathrm{DOC}}+\Delta \mathrm{C}\right)$

Equation (4) can be rearranged as in Eq. (5), to allow calculation of NPP fineroot from the other components.

$\mathrm{NPP}_{\text {fineroot }}=R_{\mathrm{SOM}}-\left(\mathrm{NPP}_{\text {litter }} \cdot F_{\text {LITTER }}\right)-\left(M_{\mathrm{AG}} \cdot F_{\mathrm{CWD}}\right)-M_{\mathrm{BG}}+F_{\mathrm{DOC}}+\Delta \mathrm{C}$

$R_{\text {SOM }}$ is the heterotrophic respiration of the soil excluding the litter layer and was directly measured through a soil partitioning experiment (see below). NPP litter is the canopy (leaves, flowers and fruit) litterfall and $F_{\text {LITTER }}$ is the fraction of this litter entering the soil (as opposed to being respired in situ in the litter layer). $M_{\mathrm{AG}}$ is the above-ground biomass lost in tree mortality in $\mathrm{MgC} \mathrm{ha}^{-1} \mathrm{yr}^{-1}$ ), the mean production of above-ground Coarse Woody Debris (CWD) over the four years of this study, and $F_{\mathrm{CWD}}$ is the fraction of this CWD entering the soil (as opposed to being respired in situ in the CWD). $M_{\mathrm{BG}}$ is the below ground biomass lost in tree mortality, all of which enters the soil. Here we assume that the dissolved organic $C$ leakage $\left(F_{\mathrm{DOC}}\right)$ and the net change in soil stocks $(\Delta \mathrm{C})$ are both zero, or at least negligible compared to the overall internal carbon cycle of the forest.

The terms $F_{\text {litter }}$ and $F_{\mathrm{CWD}}$ are poorly quantified. For lowland Amazonian forests, Malhi et al. (2009) estimated $F_{C W D}$ as $0.24 \pm 0.15$. It is unclear how these value
BGD

7, 3735-3763, 2010

Temperate woodland carbon cycle

K. Fenn et al.

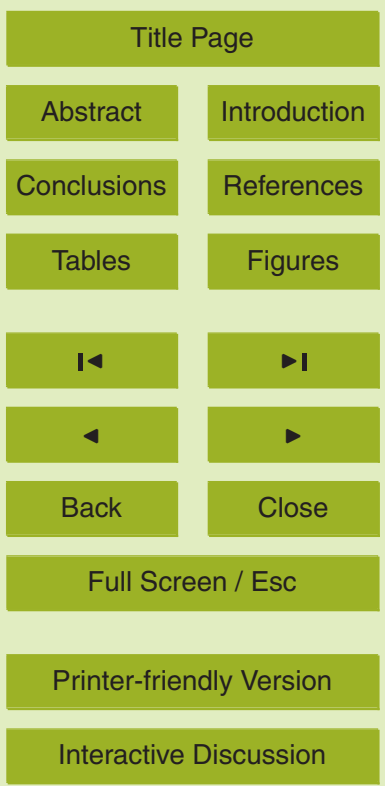

Interactive Discussion 
extrapolates to a temperate context, but it seems very likely that more than half the litter and CWD is broken down by in situ heterotrophic decomposition (by macrofauna, fungi and bacteria) rather than transport to the soil organic matter matrix. Hence we assume $F<50 \%$ and apply broad error bars to reflect the high uncertainty, i.e. $F_{\text {litter }}$ and $5 \quad F_{\mathrm{CWD}}=0.25 \pm 0.25$. The value of $F_{\text {litter }}$ only has a moderate influence on our overall NPP estimates and the value of $F_{\mathrm{CWD}}$ has almost negligible influence as the input of CWD is so small at this site.

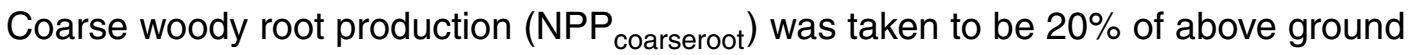
woody production (Giardina and Ryan, 2002), equal to the ratio of below-ground 10 to above-ground woody biomass typically found in temperate deciduous forests, with a conservative error estimate of $\pm 15 \%$, i.e. $0.20 \pm 0.15$. Similarly, we assume $M_{\mathrm{BG}}=(0.20 \pm 0.15) \times M_{\mathrm{AG}}$.

\subsection{Leaf production}

Annual leaf production was determined by catching subsamples of the leaves falling in 15 autumn in litter traps, and scaling up to the 1 ha plot. A $0.25 \mathrm{~m}^{2}$ litter trap was placed in each of the 25 subplots in October 2006; they remained in place to catch leaves falling in the autumns of 2007 and 2008. Traps were emptied every two weeks; the leaves were sorted into species before drying for $48 \mathrm{~h}$ at $75-80^{\circ} \mathrm{C}$ and weighing.

The Specific Leaf Area (SLA; area/mass) for each species were determined by mea20 suring the leaf area of several subsamples of each species' leaf litter, prior to leaf drying and weighing (Scion Image, Maryland, USA). The LAI of each species per sample session could then be calculated, and the total LAI of each species estimated by reverse cumulative summing of the litter caught (i.e. summing the shed LAl over preceding weeks.)

25 The seasonality of leaf production and canopy decline was recorded using the optical LAI-2000 method (LiCor, Lincoln, NE, USA). In autumn measurements were taken on the same days as litter traps were emptied to allow calibration of the optical method with actual leaf area measurements. The calibrated peak LAI value $\left(\mathrm{m}^{2} \mathrm{~m}^{-2}\right)$ was taken to

\section{BGD}

7, 3735-3763, 2010

Temperate woodland carbon cycle

K. Fenn et al.

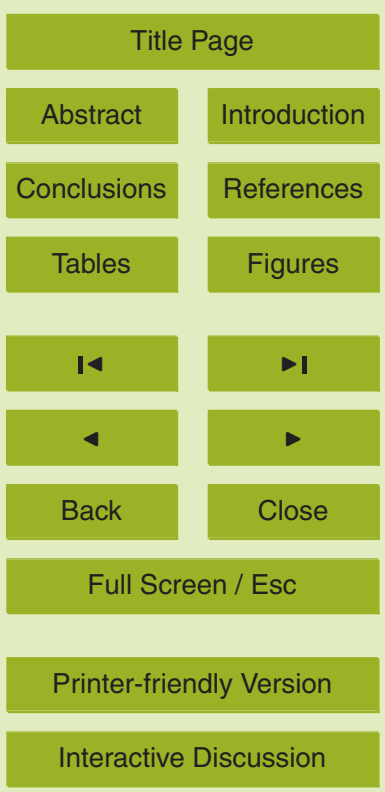


represent the total amount of leaves collected in the traps, and the relationship between the two used to estimate leaf production in the preceding months. This assumed that no new leaves were produced once peak canopy cover had been achieved and that only a very small amount of leaf material had been lost to herbivory, or that the two 5 balance. $Q$. robur is known to have a second flush of leaves "Lammas leaves", but the consistency of our summer LAI values after May suggests that this assumption is reasonable.

\subsection{Leaf respiration}

Night-time measurements of leaf respiration were made for sun and shade leaves of sycamore and oak at this site in a previous study (Stokes, 2002). These measurements were used in Eq. (6), to estimate hourly leaf respiration at each hour $t\left(R_{\mathrm{t}}\right.$, $\left.\mu \mathrm{mol} \mathrm{CO} \mathrm{C}^{-2} \mathrm{~h}^{-1}\right)$ for the study plot during 2008. Night time leaf respiration $\left(R_{\mathrm{n}}\right.$, $\mu \mathrm{mol} \mathrm{CO} \mathrm{m}^{-2} \mathrm{~s}^{-1}$ ) is calculated as from Eq. (7).

$R_{\mathrm{t}}=\left(R_{\mathrm{n}} \cdot Q_{10}\right)^{[(T 2-T 1) / 10]}$

15

$R_{\mathrm{n}}=\left\{F_{\text {sun }}\left[\left(A_{\text {sun }}+Q_{\text {sun }} / 2\right]\right\}+\left\{F_{\text {shade }}\left[\left(A_{\text {shade }}+Q_{\text {shade }}\right) / 2\right]\right\}\right.$

$T_{1}$ is air temperature at time of measurement $\left({ }^{\circ} \mathrm{C}\right), T_{2}$ is hourly mean temperature $\left({ }^{\circ} \mathrm{C}\right.$ ) at time $t$ and $Q_{10}$ is assumed to be 2 (i.e. respiration rate doubles for every $10^{\circ} \mathrm{C}$ increase in air temperature). $F_{\text {sun }}$ and $F_{\text {shade }}$ are the fraction of sun and shade leaves in the canopy. Using a sun-leaf SLA of 10 or less (Stokes, 2002) and the distribution of oak leaf SLA in sun-exposed and shaded layers of the canopy (Roberts et al., $1999), F_{\text {sun }}$ was estimated to be $39 \%$ and $F_{\text {shade }} 61 \% . A_{\text {sun }}$ and $A_{\text {shade }}$, and $Q_{\text {sun }}$ and $Q_{\text {shade }}$ are the measured values of night-time leaf dark respiration $\left(\mu \mathrm{mol} \mathrm{CO} \mathrm{C}^{-2} \mathrm{~s}^{-1}\right)$ of $A$. pseudoplatanus sun and shade, and $Q$. robur sun and shade leaves, respectively. The daytime respiration rate $\left(R_{\mathrm{d}}\right)$ cannot simply be assumed to be equal to the temperature-corrected night respiration $\left(R_{\mathrm{n}}\right)$; light inhibits dark respiration (Sharp et
BGD

7, 3735-3763, 2010

\section{Temperate woodland carbon cycle}

K. Fenn et al.

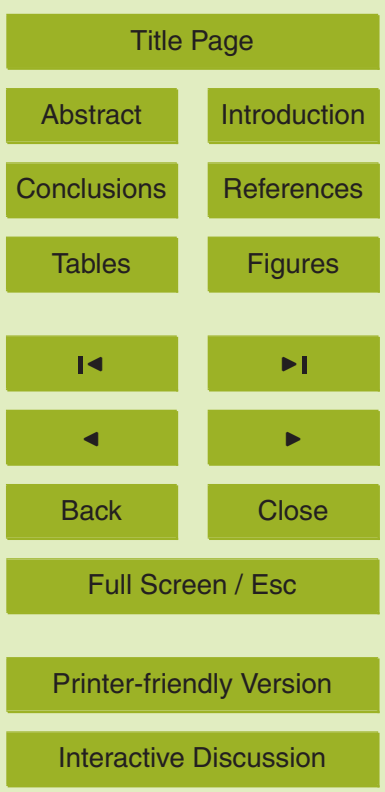


al., 1984), so $R_{\mathrm{n}}$ must be adjusted for the hours of daylight. The degree of this inhibition varies with species, leaf age, level of irradiance and temperature (Villar et al., 1995; Atkin et al., 2000). A previous study estimated the degree of inhibition of dark respiration in a deciduous shrub (Lepechinia fragans) as $61.8 \pm 4.7 \%$ (i.e. $R_{\mathrm{d}}=38.2 \times R_{\mathrm{n}}$,

5 Villar et al., 1995); this value was used here, as to our knowledge, no data exist for the species in this study. Malhi et al. (2009) applied photoinhibition of $67 \%$ for daytime leaf respiration of tropical trees. Night was defined as the hours when total solar radiation $<20 \mathrm{~W} \mathrm{~m}^{-2}$, as measured at the Upper Seeds meteorological station.

Once the adjustments for photoinhibition were made to daytime hourly leaf respira10 tion, hourly values could be summed to produce monthly and annual estimates of total leaf respiration. Our assumptions around leaf respiration (the degree of photoinhibition, the fraction of sun and shade leaves, the fraction of leaves in each species, and the temperature sensitivity) all contain potential systematic uncertainty. To be conservative we apply a large uncertainty bound of $50 \%$ for the leaf respiration estimates and 15 propagate these through our calculations. Leaf respiration is the largest source of uncertainty in our "bottom-up" quantification of the carbon cycle; it is however based on in situ measurements of the same species. The mean of the standard errors reported by Stokes (2002) for other photosynthesis measurements of the same species was $\pm 40 \%$.

\subsection{Stem respiration}

Monthly stem respiration measurements from eight $F$. excelsior and eight $A$. pseudoplatanus trees were taken from April to November 2008 (Fenn et al., 2010). The chosen trees had diameters at breast height (dbh) ranging between 22.0-40.6 and $16.3-60.1 \mathrm{~cm}$ for the two species, respectively, representing the range of tree size of these two species at this site.

Measurements were taken at fixed points on each tree, using PVC "collars" $(50 \mathrm{~mm}$ high $\times 65 \mathrm{~mm}$ diameter PVC pipe, Flowline, Marley, Maidstone, UK) attached for the duration of the study, using non-setting putty (Plumbers' Mait, Evostik, Bostik Ltd,

\section{BGD}

7, 3735-3763, 2010

\section{Temperate woodland carbon cycle}

K. Fenn et al.

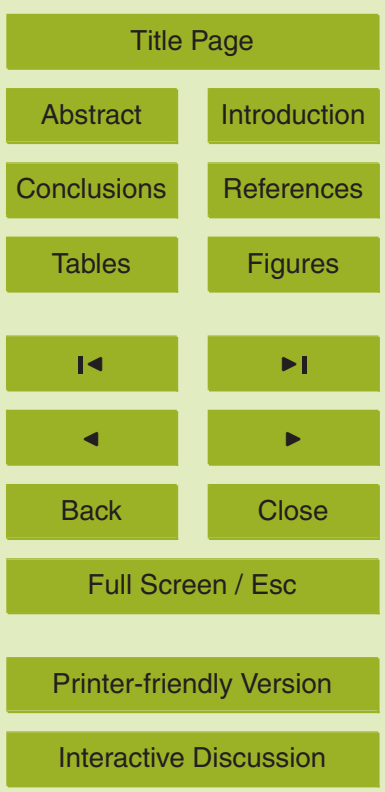

Interactive Discussion 
Leicester, UK) to allow change in tree diameter. The collars were fixed on south-facing areas of stem with no wounds or growing/dormant buds, which were flat enough to accommodate the collars and as close as possible to breast height $(1.3 \mathrm{~m})$.

Respiration measurements were made using a portable infra-red gas analysis sys5 tem (EGM-4 and SRC-1 soil chamber, PP Systems, Hitchin, UK), with an adaptor custom-made to fit the collars. To maximise comparability between measurement sessions, all measurements were taken between 09:00 and 13:00 GMT.

Respiration rates in $\mu \mathrm{mol} \mathrm{CO}_{2} \mathrm{~m}^{-2} \mathrm{~s}^{-1}$ were scaled up to plot-level estimates of monthly and annual stem respiration ( $\left.\mathrm{MgCha}^{-1} \mathrm{y}^{-1}\right)$ using Eq. (8) (Whittaker and 10 Woodwell, 1967), which calculates tree stem and branch surface area $\left(S, \mathrm{~cm}^{2}\right)$ from stem and branch woody biomass (ABW, g).

$\log _{10} S=1.2980+0.8259 \log _{10}$ ABW

This equation was derived from the relationship between stem and branch surface area and woody biomass in woody temperate species (Quercus alba, Q. coccinea, Q. ilicifoloa, Liriodendron tulipifera, Pinus rigida, P. echinata, Rhododendron maximum, Gaylussacia baccata and Vaccinium vacillans), harvested at the Brookhaven National Laboratory and Oak Ridge National Laboratory centres, US. No dbh data were collected in January and February 2008, so zero growth was assumed for these winter months and the March 2008 ABW values were used for January and February. The 20 Stem Area Index (SAI) of this plot was calculated to be $1.94 \mathrm{~m}^{2} \mathrm{~m}^{-2}$.

The calculated stem area for each tree in each month was then multiplied by the stem $\mathrm{CO}_{2}$ efflux rate for that month. For A. pseudoplatanus and F. excelsior their speciesspecific stem efflux rates were used, for all other species a mean of these rates was used. These rates were summed to produce monthly and annual estimates of stem
BGD

7, 3735-3763, 2010

\section{Temperate woodland carbon cycle}

K. Fenn et al.

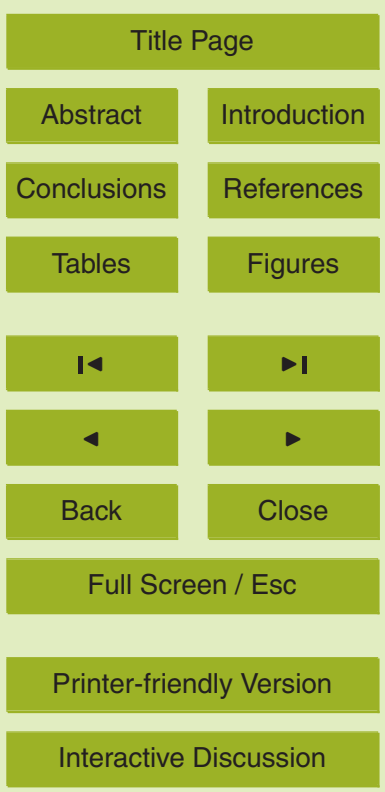




\subsection{Soil respiration}

Soil $\mathrm{CO}_{2}$ efflux measurements were made using a portable infra-red gas analysis system and soil $\mathrm{CO}_{2}$ efflux chamber (PP Systems, Hitchin, UK) modified with a custommade adaptor to fit soil "collars" used as fixed measurement points. One measurement

5 was carried out per subplot, per session, except in the four corners of the plot where three were taken to check for measurement consistency. The mean of these replicates was taken with each of the other individual measurements to generate the plot mean $\mathrm{CO}_{2}$ efflux rate, used in the subsequent analysis. Soil respiration measurements were made from 13 February to 23 November 2007, and 1 April to 14 December 2008. To approximate the efflux in the missing winter months the mean of all measurements made on 30 November 2006 and 13 February 2007 were used for January 2007, and of 23 November and 1 April 2008 for December 2007 to April 2008. As winter efflux rates are low compared to those in summer it is hoped that any inaccuracies arising from this estimation method have little effect on annual Reco. Mean monthly total soil 15 respiration used all measurements taken within each month, excluding the extra corner measurements. Surface litter was removed prior to efflux measurements as the amount of litter varied seasonally over the year.

We partitioned total soil $\mathrm{CO}_{2}$ efflux into root and rhizosphere, mycorrhizal, and SOM components using micromesh bags (Plastok Ltd, Birkenhead, UK) (Moyano et al., 2007, 2008; Heinemeyer et al., 2007) installed in nine of the 25 subplots (a t-test paired by month showed no significant difference in mean efflux between the nine and 25 subplots, $\mathrm{P}=0.38$ ). The bags enclosed a core of soil in-situ, from which $\mathrm{CO}_{2}$ efflux measurements were repeatedly taken throughout the 2008 growing season (Fenn et al., 2010). Two mesh sizes were used producing three 'partitions' of soil $\mathrm{CO}_{2}$ efflux. 25 From these partitions, the relative contributions of heterotrophic respiration of soil organic matter $\left(R_{\mathrm{SOM}}\right)$, mycorrhizas $\left(R_{\mathrm{MYC}}\right)$ and roots and their rhizosphere $\left(R_{\mathrm{RRHIZ}}\right)$ to total soil $\mathrm{CO}_{2}$ efflux $\left(R_{\mathrm{SOIL}}\right)$ can be determined by subtraction. Both mesh sizes allow the passage of water.
BGD

7, 3735-3763, 2010

Temperate woodland carbon cycle

K. Fenn et al.

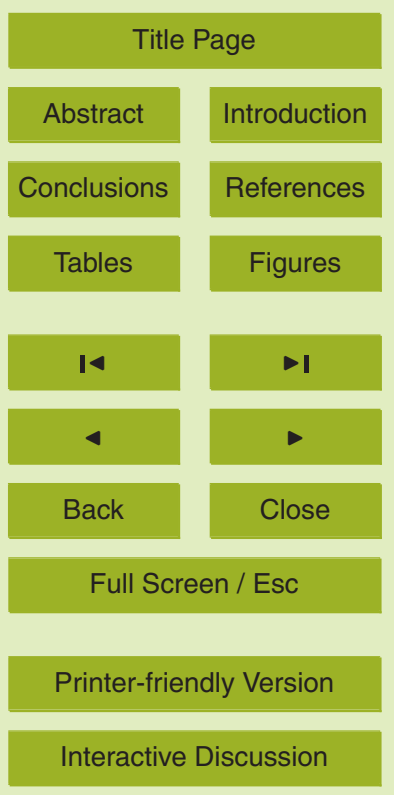

Interactive Discussion 
Mesh bags were installed in January 2008, to allow the soil within them to equilibrate with the surrounding soil before the growing season brought an increase of soil respiratory activity. $\mathrm{CO}_{2}$ efflux measurements were made approximately every two weeks between 15 April 2008 and 26 November 2008.

Mean soil temperature over $0-150 \mathrm{~mm}$ depth (Digital Waterproof Thermometer, Barnstead International, Dubuque, USA) and volumetric soil water content over 0$200 \mathrm{~mm}$ depth (Hydrosense meter, Campbell Scientific, Australia) were measured within $2 \mathrm{~m}$ of respiration collars during each total and partitioned soil $\mathrm{CO}_{2}$ efflux measurement.

\subsection{Leaf decomposition}

Litter bag estimates of monthly leaf litter decomposition were made at this site, following the method of Robertson et al. (1999), to determine the seasonal trend of litter C loss. Over an extended period it is however assumed that litter production and decomposition are in equilibrium. Therefore, using the mass balance approach, the amount of litter $\mathrm{C}$ entering the soil annually $\left(S_{\text {LITTER }}\right)$ can be estimated, using $F_{\text {LITTER }}$ estimated as $25 \% \pm 25 \%$ of fallen litter $\left(\mathrm{NPP}_{\text {LITTER }}=\mathrm{NPP}_{\mathrm{LEAF}}+\mathrm{NPP}_{\text {REPRODUCTIVE}}\right.$, as for root production). The $\mathrm{C}$ released to the atmosphere from decompositional respiration of the litter $\left(R_{\text {LITTER }}\right)$ can also then be estimated, as NPP LITTER $-S_{\text {LITTER }}$.

\subsection{Eddy covariance estimates of GPP and $R_{\mathrm{ECO}}$}

20 Eddy covariance data collection at the site began in June 2007; the data used here are from this date to 31 December 2008. Details of the analysis methods used and results are described in detail in the companion paper by Thomas et al. (2010). The instrumentation is $25 \mathrm{~m}$ above the ground on a tower located close to the centre of the plot. Thomas et al. (2010) estimated GPP and $R_{\mathrm{ECO}}$ (and Net Ecosystem Productivity, NEP) from the data using the CarboEurope partitioning tool (Reichstein et al., 2006), with GPP being NEP- $R_{\mathrm{ECO}}$.
BGD

7, 3735-3763, 2010

Temperate woodland carbon cycle

K. Fenn et al.

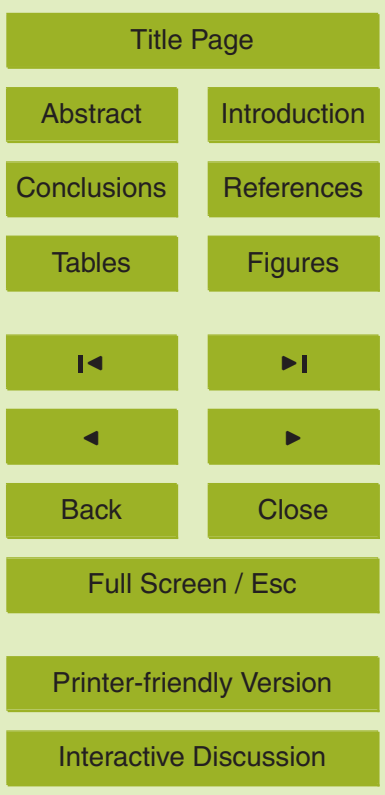


The eddy covariance derived estimates of GPP and $R_{\mathrm{ECO}}$ were then compared with those produced using the biometric and chamber measurements, where the biometric estimate of GPP is calculated as in Eq. (9).

$$
\mathrm{GPP}=R_{\mathrm{AUTO}}+\mathrm{NPP}_{\text {total }}
$$

5 This assumes that carbon gain through photosynthesis equals carbon use through respiration of NPP. It assumes that there is negligible interannual variation in internal storage of photosynthate, in the form of non-structural carbohydrates.

\section{Results}

\subsection{NPP}

10 The largest component of productivity is leaf production, accounting for over half of total NPP (Table 1). Whilst deciduous tree leaf production in any given year requires the remobilisation of resources stored in the previous growing season, this production is here allocated to the year in which the leaves are produced and so that year's NPP. The majority of NPP is above-ground; the production of leaves, wood and reproductive structures, contribute approximately $60 \%$ of total NPP. A small amount of trunk expansion occurs during the months of canopy production, but significant wood production begins once the canopy is established and photosynthesising, increasing to a peak in August then decreasing through autumn (Fig. 1).

\subsection{Ecosystem respiration}

20 The greatest component of $R_{\mathrm{ECO}}$ is $R_{\mathrm{STEM}}$, releasing $8.8 \mathrm{Mg} \mathrm{Cha}^{-1} \mathrm{yr}^{-1}$ in 2008 (Table 2), $46.8 \pm 1.3 \%$ of total $R_{\mathrm{ECO}}$. $R_{\mathrm{LEAF}}$ is the second greatest contributor over the whole year, only producing more $\mathrm{Mg} \mathrm{C}$ than $R_{\mathrm{STEM}}$ during August, the month of highest wood production rate, when $R_{\text {STEM }}$ itself drops slightly. $R_{\text {STEM }}$ also continues throughout the winter months of dormancy, at a reduced rate, as maintenance respiration. Both 3748

\section{BGD}

7, 3735-3763, 2010

Temperate woodland carbon cycle

K. Fenn et al.

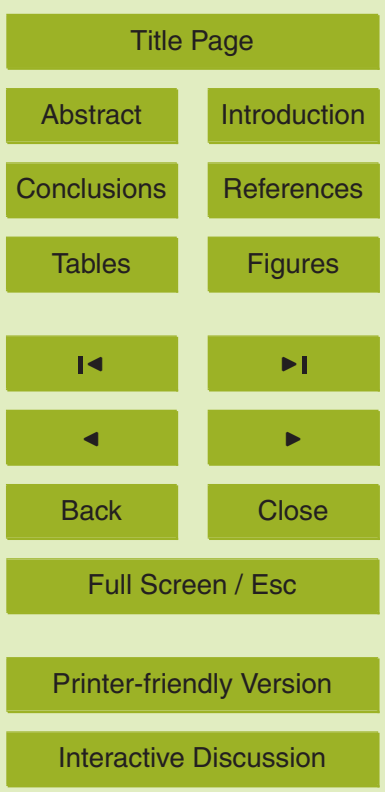

Interactive Discussion 
$R_{\mathrm{STEM}}$ and $R_{\mathrm{LEAF}}$ are influenced by temperature and tree growing season, with $R_{\mathrm{LEAF}}$, by definition, only occurring when leaves are present and metabolically active.

The clear seasonal cycle of $R_{\mathrm{ECO}}$ produced when the components are combined (Fig. 2a) closely matches the independent estimate of $R_{\mathrm{ECO}}$ estimate produced by 5 eddy covariance (Fig. 2b), except in September, when there is a discrepancy between them of $1.19 \mathrm{MgC}$.

\subsection{Carbon cycle of the forest plot}

The above-ground components are the greatest contributors to both productivity and respiration, as $\mathrm{NPP}_{\text {leaf }}, \mathrm{NPP}_{\text {wood }}$ and $R_{\mathrm{STEM}}, R_{\mathrm{LEAF}}$, and $R_{\mathrm{LITTER}}$, respectively (Table 3). 10 Of these, leaf production contributes the greatest portion of $\mathrm{NPP}_{\text {total }}(40.2 \%)$, but stem respiration the greatest portion of $R_{\mathrm{ECO}}(45.6 \%)$. The Carbon-Use Efficiency (CUE) of this site, the proportion of GPP used for biomass production rather than respiration, is $0.35 \pm 0.05$.

\section{Discussion}

\section{$15 \quad 4.1$ Productivity}

We estimate the annual NPP of this system at $7.0 \pm 0.8 \mathrm{MgCha}^{-1} \mathrm{yr}^{-1}$. Studies at temperate deciduous sites using comparable inventory methods are rare, but Ohtsuka et al. (2002) estimated NPP to be $5.7 \mathrm{Mg} \mathrm{Cha}^{-1} \mathrm{yr}^{-1}$ for a site in Japan using a similar methodology to this study. Both sites have been disturbed by some tree removal in the past and now contain secondary growth, whilst remaining as broadleaved deciduous forest. Compared to NPP values reported for managed temperate deciduous forests of $17.7 \mathrm{MgCha}^{-1} \mathrm{yr}^{-1}$ (Curiel Yuste et al., 2005a), 6.3 $\mathrm{Mg} \mathrm{Cha}^{-1} \mathrm{yr}^{-1}$ (LeMaire et al., 2005) and 2.7 and 3.8 $\mathrm{Mg} \mathrm{Cha}^{-1} \mathrm{yr}^{-1}$ (for two consecutive years; Ehman et al., 2002), this demonstrates that relatively unmanaged woodlands, such as Wytham, can also be quite productive.

BGD

7, 3735-3763, 2010

\section{Temperate woodland carbon cycle}

K. Fenn et al.

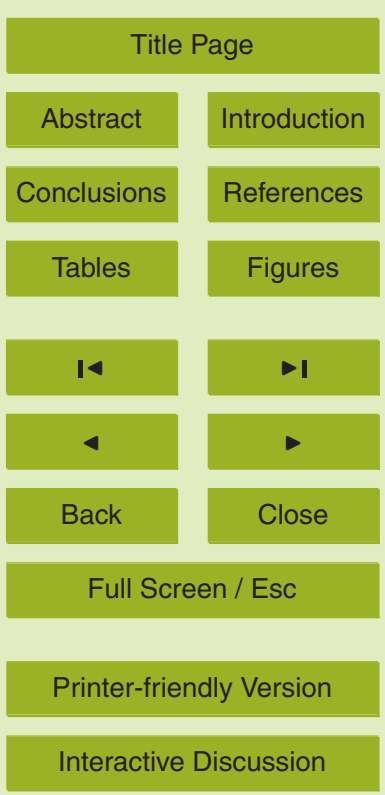

Interactive Discussion 
The clear monthly data on woody productivity demonstrate the value of this scale of dendrometer dbh change measurements. The ability of this simple method to detect monthly changes in the growth of these temperate species enabled us to gain clear insight into the seasonality of wood production at this site. Combining dendrometer 5 data with LAI measurements showed how the production of leaves, concentrated in late spring, was immediately followed by an increase in trunk growth, peaking in August.

The production of leaves in deciduous trees requires the reallocation of resources acquired and stored in the previous growing season. In this system leaf production is the greatest component of total NPP, contributing $38 \%$ (where leaf production is 10 allocated to the year in which they appear, rather than the previous year), revealing the high level of internal C-cycling within these trees. Stokes et al. (2010) used carbon isotope $\left({ }^{13} \mathrm{C}:{ }^{12} \mathrm{C}\right)$ ratios in oak and sycamore leaves at Wytham to show that much of this internal cycling is likely to take place within individual branches, as isotopic signatures of sun and shade branches are maintained.

15 Here $36 \%$ of total NPP was allocated belowground, in the centre of the range of previous findings of $15.2-55.1 \%$ for a temperate Quercus and Fraxinus forest (Tateno et al., 2004), 54\% for a regenerated mixed deciduous temperate site (Newman et al., 2006) and $27 \%$ in a Siberian Larix forest. This is a substantial component of NPP (particularly fine root production) that can be missed by traditional studies that have

\subsection{Respiration}

The seasonality of the biometric and tower estimates of $R_{\mathrm{ECO}}$ was remarkably close for the majority of months. There was a discrepancy in September of $1.19 \mathrm{MgC}$, which may be an artefact of measurement date. Whilst the eddy covariance data

mon $R_{\text {STEM }}$ monthly. This is a period of transition at the end of the tree growing season and it is possible that the spot measurements of $R_{\mathrm{STEM}}$ and $R_{\mathrm{SOIL}}$ were unrepresentative of the month as a whole.

\section{BGD}

7, 3735-3763, 2010

\section{Temperate woodland carbon cycle}

K. Fenn et al.

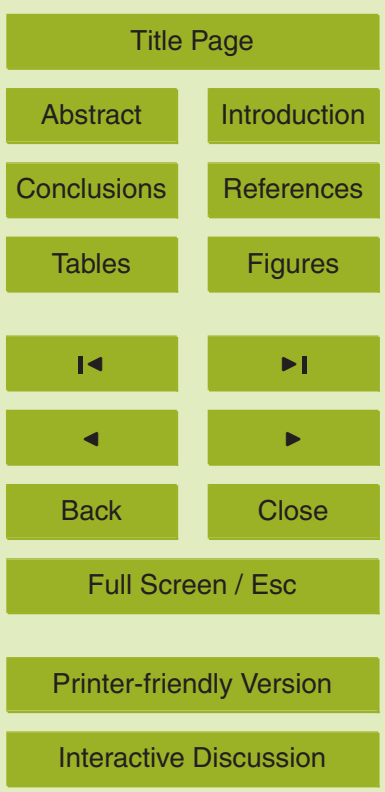

Interactive Discussion 
The percentage contribution of each respiration component to $R_{\mathrm{ECO}}$ at this site differs from that at other locations which have been measured, with $R_{\text {STEM }}$ being the greatest contributor here, as opposed to $R_{\mathrm{SOIL}}$ at other sites (Table 4 ). The very high levels of stem respiration are noteworthy and unusual, particularly given the relatively low

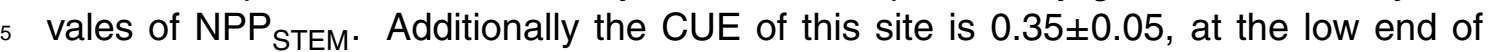
the $0.34-0.83$ reported for a range of temperate deciduous forests (DeLucia et al., 2007 ). This suggests that there is a higher level of autotrophic respiration, likely $R_{\text {STEM }}$ in particular, compared to production at Wytham, compared to other sites. This may result from higher winter respiration rates as a result of the relatively warm winters 10 associated with the oceanic climate at this site.

Both $R_{\mathrm{ECO}}$ and GPP rely on accurate measurements of a large number of parameters, and their accurate up-scaling, and further characterisation of the way these parameters vary between ecosystems would be useful.

\section{Conclusions}

15 We have demonstrated the feasibility of quantifying many of the components of the forest carbon cycle within a coherent framework. The close agreement between not just the annual but also monthly $R_{\mathrm{ECO}}$ estimates from biometric and eddy covariance methods give us confidence in the robustness and suitability of both the methods used and increases confidence that no large components of the carbon cycle have been missed.

20 There is also a very close agreement between the tower and biometric estimates of GPP; 21.1 and $20.3 \pm 1.0 \mathrm{MgCha}^{-1} \mathrm{yr}^{-1}$, respectively. These biometric methods can therefore be used with greater confidence at sites unsuitable for eddy covariance, such as those with a small fetch, or uneven topography and in any case provide much greater insight into the carbon dynamics of the forest.

25 Acknowledgements. Many thanks to everyone who assisted with this work, in particular Michèle Taylor and NERC for the Upper Seeds meteorological data collected under the Environmental Change Network programme, Dave McNeil for installing and maintaining the eddy

\section{BGD}

7, 3735-3763, 2010

\section{Temperate woodland carbon cycle}

K. Fenn et al.

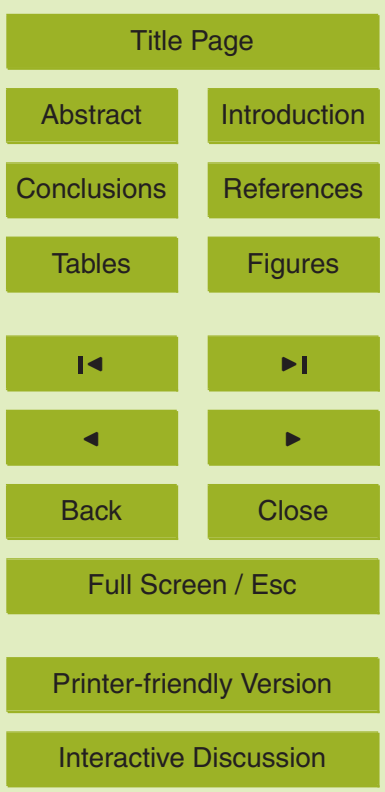

Interactive Discussion 
covariance equipment, and Terhi Riutta and Earthwatch-HSBC volunteers for collecting and sorting the autumn 2008 leaf litter. KMF's D. Phil studentship was funded by the Natural Environment Research Council through the Centre for Ecology and Hydrology.

\section{References}

5 Atkin, O. K., Evans, J. R., Ball, M. C., Lambers, H., and Pons, T. L.: Leaf respiration of snow gum in the light and dark, Interactions between temperature and irradiance, Plant Physiol., 122, 915-923, 2000.

Beard, G. R.: The soils of Oxford University Field Station, Wytham, Soil Survey and Land Research Centre Silsoe (now National Soil Resources Institute, Cranfield University), 1993.

Bolstad, P. V., Davis, K. J., Martin, J., Cook, B. D., and Wang, W.: Component and wholesystem respiration fluxes in northern deciduous forests, Tree Physiol., 24, 493-504, 2004.

Bunce, R. G. H.: Biomass and production of trees in a mixed deciduous woodland: I. Girth and height as parameters for the estimation of tree dry weight, J. Ecol., 5, 759-775, 1968.

Butt, N., Campbell, G., Malhi, Y., Morecroft, M., Fenn, K., and Thomas, M.: Initial results from Establishment of a Long-term Broadleaf Monitoring Plot at Wytham Woods, http://www. eci.ox.ac.uk/publications/downloads/butt09-wythamwoods.pdf, last access: 20 April 2010, University of Oxford, Oxford, UK, 2009.

Curiel Yuste, J., Konôpka, B., Janssens, I. A., Coenen, K., Xiao, C. W., and Ceulemans, R.: Contrasting net primary productivity and carbon distribution between neighboring stands of Quercus robur and Pinus sylvestris, Tree Physiol., 25, 701-712, 2005a.

Curiel Yuste, J., Nagy, M., Janssens, I. A., Carrara, A., and Ceulemans, R.: Soil respiration in a mixed temperate forest and its contribution to total ecosystem respiration, Tree Physiol., 25, 609-619, 2005b.

Curtis, P. S., Hanson, P. J., Bolstad, P., Barford, C., Randolph, J. C., Schmid, H. P., and Wilson, K. B.: Biometric and eddy-covariance based estimates of annual carbon storage in five eastern North American deciduous forests, Agr. Forest Meteorol., 113, 3-19, 2002.

DeLucia, E. H., Drake, J. E., Thomas, R. B., and Gonzalez-Melers, M.: Forest carbon use efficiency: is respiration a constant fraction of gross primary production?, Global Change Biol., 13, 1157-1167, 2007.

\section{BGD}

7, 3735-3763, 2010

\section{Temperate woodland carbon cycle}

K. Fenn et al.

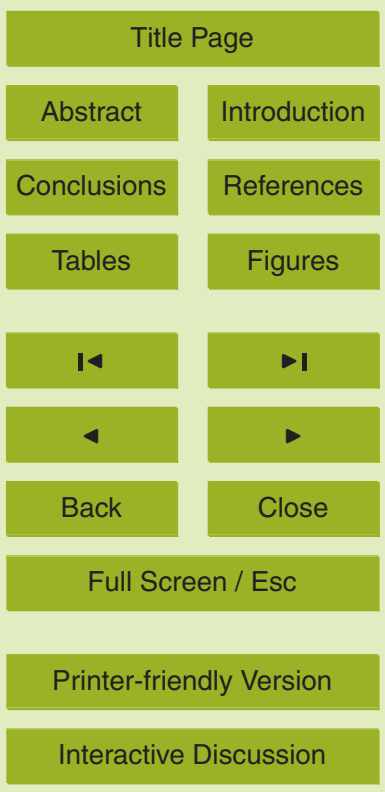


Ehman, J. L., Schmid, H. P., Grimmond, C. S. B., Randolph, J. C., Hanson, P. J., Wayson, C. A., and Cropley, F. D.: An initial intercomparison of micrometeorological and ecological inventory estimates of carbon exchange in a mid-latitude deciduous forest, Global Change Biol., 8, 575-589, 2002.

5 Falge, E., Baldocchi, D., Tenhunen, J., Abinet, M., Bakwin, P., Berbigier, P., Bernhofer, C., Burba, G., Clement, R., Davis, K. J., Elbers, J. A., Goldstein, A. H., Grelle, A., Granier, A., Gudmundsson, J., Hollinger, D., Kowalski, A. S., Katul, G., Law, B. E., Malhi, Y., Meyers, Y., Monson, R. K., Munger, J. W., Oechel, W., Paw, U. K. T., Pilegaard, K., Rannik, Ü., Rebmann, C., Suyker, A., Valentini, R., Wilson, K., and Wofsy, S.: Seasonality of ecosystem respiration and gross primary production as derived from FLUXNET measurements, Agr. Forest Meteorol., 113, 53-74, 2002.

Fenn, K. M.: Carbon Cycling in British Deciduous Woodland: Processes, Budgets, Climate and Phenology, D. Phil Thesis, 2010.

Fenn, K. M., Malhi, Y., and Morecroft, M. D.: Soil $\mathrm{CO}_{2}$ efflux in a British temperate deciduous forest: environmental drivers of interannual variability, and component contributions, submitted to Soil Biol. Biochem., 2010.

Giardina, C. P. and Ryan, M. G.: Total belowground carbon allocation in a fast-growing Eucalyptus plantation estimated using a carbon balance approach, Ecosystems, 5, 487-499, 2002.

20 Granier, A., Ceschia, E., Damesin, C., Dufrêne, E., Epron, D., Gross, P., Lebaube, S., Le Dantec, V., Le Goff, N., Lemoine, D., Lucot, E., Ottorini, J. M., Pontailler, J. Y., and Saugier, B.: The carbon balance of a young Beech forest, Funct. Ecol., 14, 312-325, 2000.

Griffis, T. J., Black, T. A., Gaumont-Gay, D., Drewitt, G. B., Nesic, Z., Barr, A. G., Moregenstern, K., and Kljun, N.: Seasonal variation and partitioning of ecosystem respiration in a southern boreal aspen forest, Agr. Forest Meteorol., 125, 207-223, 2004.

Hall, J. E., Kirby, K. J., and Whitbread, A. M.: National Vegetation Classification: Field guide to woodland, Joint Nature Conservation Committee, Peterborough, UK, 2004.

Heinemeyer, A., Hartley, I. P., Evans, S. P., Carreira De La Fuentes, J. A., and Ineson, P.: Forest soil $\mathrm{CO}_{2}$ flux: uncovering the contribution and environmental responses of ectomycorrhizas, Global Change Biol., 13, 1-12, 2007.

Keeland, M. and Young, B. D.: Construction and Installation of Dendrometer Bands: http: //www.nwrc.usgs.gov/Dendrometer/index.htm, last access: 13 January 2009.
BGD

7, 3735-3763, 2010

\section{Temperate woodland carbon cycle}

K. Fenn et al.

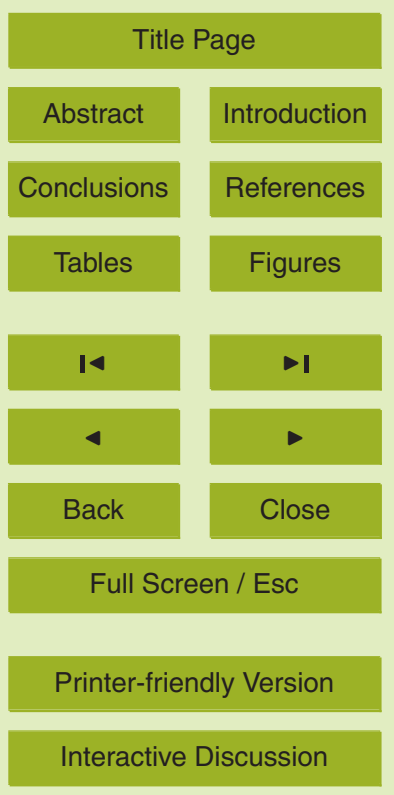


Kirby, K. J. and Thomas, R. C.: Changes in the ground flora in Wytham Woods, southern England from 1974 to 1991: Implications for nature conservation, J. Veg. Sci., 11, 871-880, 2000.

LeMaire, G., Davi, H., Soudani, K., François, C., LeDantec, V., and Dufrêne, E.: Modelling 5 annual production and carbon fluxes of a large managed temperate forest using forest inventories, satellite data and field measurements, Tree Physiol., 25, 859-872, 2005.

Malhi, Y., Aragão, L. E. O. C., Metcalfe, D. B., Pavia, R., Quesada, C. A., ALmedia, S., Anderson, L., Brando, P., Chambers, J. Q., DaCosta, A. C. L., Hutyra, L. R., Oliveira, P. O., Patino, S., Pyle, E. H., Robertson, A., and Teixeira, L. M.: Comprehensive assessment of carbon productivity, allocation and storage in three Amazonian forests, Global Change Biol., 15, 1255-1274, 2009.

Morecroft, M. D., Taylor, M. E., and Oliver, H. R.: Air and soil microclimates of deciduous woodland compared to an open site, Agr. Forest Meteorol., 90, 141-156, 1998.

Moyano, F. E., Kutsch, W. L., and Schultze, E.-D.: Response of mycorrhizal, rhizosphere and 15 Soil basal respiration to temperature and photosynthesis in a barley field, Soil Biol. Biochem., 39, 843-853, 2007.

Moyano, F. E., Kutsch, W. L., and Rebmann, C.: Soil respiration in relation to photosynthetic activity in broad-leaf and needle-leaf forest stands, Agr. Forest Meteorol., 148, 135-143, 2008.

20 Newman, G. S., Arthur, M. A., and Muller, R. N.: Above- and belowground net primary production in a temperate mixed deciduous forest, Ecosystems, 9, 317-329, 2006.

Ohtsuka, T., Akiyama, T., Hasimoto, Y., Inatomi, M., Sakai, T., Jia, W., Mo, W., Tsuda, S., and Koizumi, H.: Biometric based estimates of net primary production (NPP) in a cool-temperate deciduous forest stand beneath a flux tower, Agr. Forest Meteorol., 134, 27-38, 2005.

Peterken, G. F. and Game, M.: Historical factors affecting the number and distribution of vascular plant species in the woodlands of Central Lincolnshire, J. Ecol., 72, 155-182, 1984.

Roberts, J., Hopkins, R., and Morecroft, M.: Towards a predictive description of forest canopies from litter properties, Funct. Ecol., 13, 265-272, 1999.

Robertson, G. R., Coleman, D. C., Bledsoe, C. S., and Sollins, P.: Standard Soil Methods for Long-Term Ecological Research, LTER, Oxford University Press, New York, USA, 1999.

Sharp, R. E., Matthews, M. A., and Boxer, J. S.: Kok effect and the quantum yield of photosynthesis, Plant Physiol., 75, 95-101, 1984.

\section{BGD}

7, 3735-3763, 2010

\section{Temperate woodland carbon cycle}

K. Fenn et al.

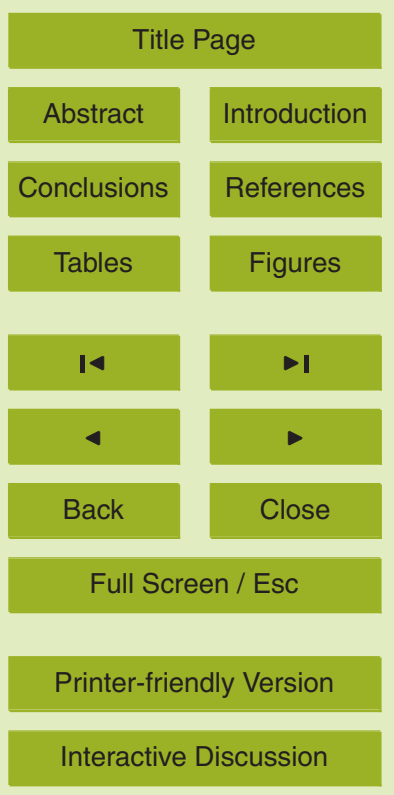


Stokes, V. J.: The impact of microenvironment, leaf development and phenology on annual carbon gain and water loss of two deciduous tree species, PhD Thesis, Department of Biological Sciences, University of Essex, 2005.

Stokes, V. J., Morecroft, M. D., and Morison, J. I. L.: Comparison of leaf water use efficiency of oak and sycamore in the canopy over two growing seasons, Trees, 24, 297-306, 2010.

Thomas, M. V., Malhi, Y., Fenn, K. M., Fisher, J. B., Morecroft, M. D., Lloyd, C. R., Taylor, M. E., and McNeil, D. D.: Carbon dioxide fluxes over an ancient broadleaved deciduous woodland in southern England, Biogeosciences Discuss., 7, 3765-3814, doi:10.5194/bgd-7-3765-2010, 2010.

10 Valentini, R., De Angelis, P., Matteucci, G., Monaco, R., Dore, S., and Scarascia Mugnozza, G. E.: Seasonal net carbon dioxide exchange of a beech forest with the atmosphere, Global Change Biol., 2, 199-207, 1996.

Villar, R., Held, A. A., and Merino, J.: Dark leaf respiration in light and darkness of an evergreen and a deciduous plant species, Plant Physiol., 107, 421-427, 1995.

Whittaker, R. H. and Woodwell, G. M.: Surface area relations of woody plants and forest communities, Am. J. Bot., 54, 931-939, 1967.

\section{BGD}

7, 3735-3763, 2010

\section{Temperate woodland carbon cycle}

K. Fenn et al.

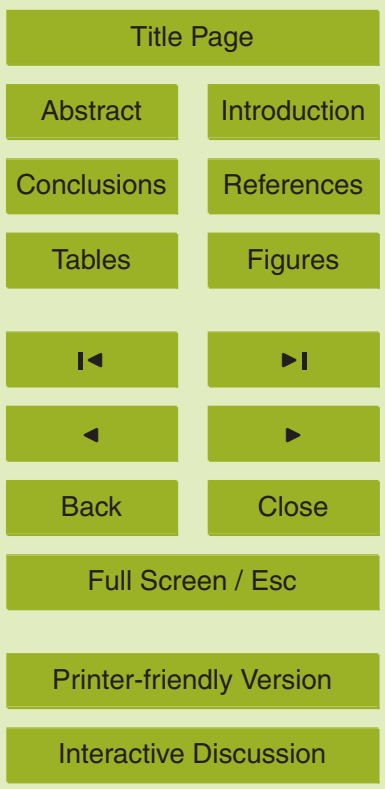


BGD

7, 3735-3763, 2010

\section{Temperate woodland} carbon cycle

\section{K. Fenn et al.}

Table 1. Annual NPP of each measured component for 2007 and 2008, calculated belowground components for 2008, plot total annual NPP for 2008.

\begin{tabular}{lcc}
\hline Component $\left(\mathrm{MgC} \mathrm{ha}^{-1} \mathrm{yr}^{-1}\right)$ & 2007 & 2008 \\
\hline NPP coarse wood & $1.25 \pm 0.11$ & $1.65 \pm 0.16$ \\
NPP leaf & $1.84 \pm 0.15$ & $2.40 \pm 0.20$ \\
NPP reproductive & $0.32 \pm 0.03$ & $0.37 \pm 0.07$ \\
NPP above-ground & $3.41 \pm 0.19$ & $4.42 \pm 0.26$ \\
\hline NPP coarse root & $0.25 \pm 0.19$ & $0.33 \pm 0.25$ \\
NPP fine root & - & $2.29 \pm 0.76$ \\
NPP below-ground & - & $2.62 \pm 0.80$ \\
\hline NPP total & - & $7.04 \pm 0.84$ \\
\hline
\end{tabular}

\section{Title Page}

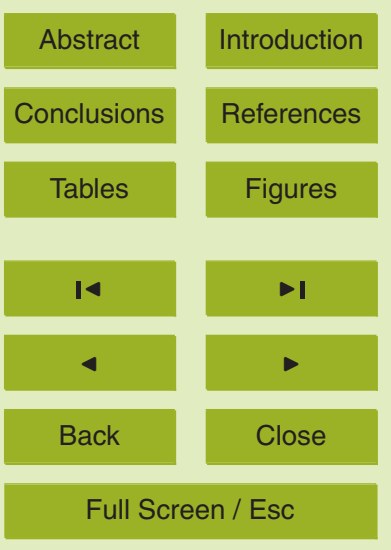

Printer-friendly Version

Interactive Discussion 


\section{BGD}

7, 3735-3763, 2010

\section{Temperate woodland} carbon cycle

Table 2. Annual respiration of each measured component, plot total annual $R_{\mathrm{ECO}}$ Biometric, and eddy covariance estimated $R_{\mathrm{ECO}}$ Tower. $R_{\mathrm{RRHIZ}}, R_{\mathrm{MYC}}$ and $R_{\mathrm{SOM}}$ sum to produce $R_{\mathrm{SOIL}}$.

\begin{tabular}{lcc}
\hline Respiration component $\left(\mathrm{MgC} \mathrm{ha}^{-1} \mathrm{yr}^{-1}\right)$ & 2007 & 2008 \\
\hline$R_{\text {RRHIZ }}$ & - & $0.9 \pm 0.2$ \\
$R_{\text {MYC }}$ & - & $0.3 \pm 0.1$ \\
$R_{\text {SOM }}$ & - & $3.0 \pm 0.3$ \\
$R_{\text {SOIL }}$ & $4.1 \pm 0.0$ & $4.10 \pm 0.09$ \\
$R_{\text {STEM }}$ & $8.9 \pm 0.1$ & $8.79 \pm 0.00$ \\
$R_{\text {LEAF }}$ & - & $4.9 \pm 0.1$ \\
$R_{\text {LITTER }}$ & - & $2.08 \pm 0.69$ \\
$R_{\text {CWD }}$ & - & $0.03 \pm 0.01$ \\
$R_{\text {AUTO }}$ & - & $13.87 \pm 0.55$ \\
$R_{\text {HET }}$ & - & $5.41 \pm 0.76$ \\
\hline$R_{\text {ECO }}$ Biometric & - & $18.9 \pm 1.7$ \\
$R_{\text {ECO }}$ Tower & - & 19.8 \\
\hline
\end{tabular}

\section{K. Fenn et al.}

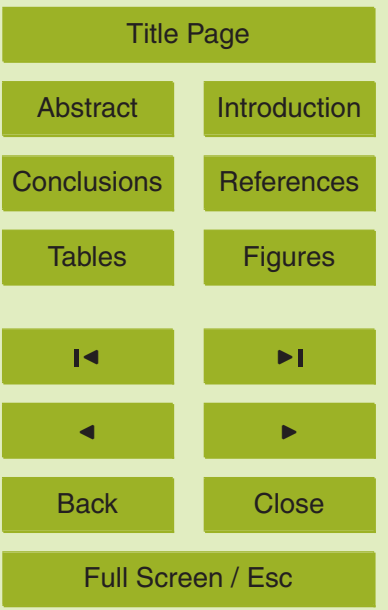

Printer-friendly Version

Interactive Discussion 
BGD

7, 3735-3763, 2010

\section{Temperate woodland} carbon cycle

\section{K. Fenn et al.}

Table 3. Above-, below-ground and total NPP, the ratio of below- to above-ground NPP, proportions of NPP allocated below- and above-ground, GPP and CUEeco.

\begin{tabular}{lr}
\hline Component $\left(\mathrm{Mg} \mathrm{Cha}^{-1} \mathrm{yr}^{-1}\right)$ & 2008 \\
\hline NPP above-ground & $4.42 \pm 0.26$ \\
NPP below-ground & $2.62 \pm 0.80$ \\
NPP total & $7.04 \pm 0.84$ \\
\hline $\mathrm{NPP}_{\mathrm{bg}} / \mathrm{NPP}_{\mathrm{ag}}$ & $0.59 \pm 0.18$ \\
$\mathrm{NPP}_{\mathrm{bg}} / \mathrm{NPP}_{\text {total }}$ & $0.37 \pm 0.12$ \\
$\mathrm{NPP}_{\mathrm{ag}} / \mathrm{NPP}_{\text {total }}$ & $0.62 \pm 0.08$ \\
$\mathrm{GPP}$ & $20.27+1.00$ \\
$\mathrm{CUE}_{\text {eco }}\left(\mathrm{NPP}_{\text {total }} / \mathrm{GPP}\right)$ & $0.35 \pm 0.04$ \\
\hline
\end{tabular}

Title Page

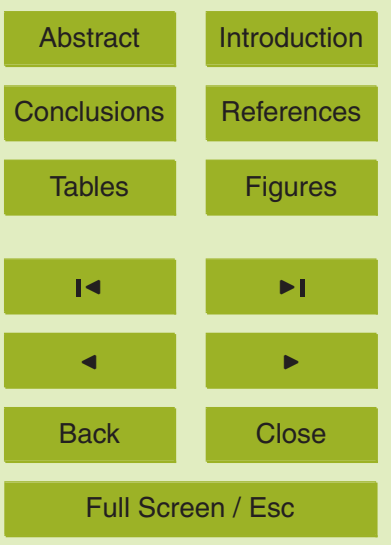

Printer-friendly Version

Interactive Discussion 
BGD

7, 3735-3763, 2010

Temperate woodland carbon cycle

K. Fenn et al.

Table 4. Percentage contribution of each respiration component to total $R_{\mathrm{ECO}}$, in this and previous studies. $R_{\mathrm{SOIL}}$ and $R_{\mathrm{DECOMP}}$ for this site are combined for ease of comparison with the other studies.

\begin{tabular}{|c|c|c|c|c|c|c|}
\hline $\begin{array}{l}R_{\mathrm{ECO}} \\
\left(\mathrm{MgCha} \mathrm{hr}^{-1}\right)\end{array}$ & $\begin{array}{l}R_{\text {SOIL }} \\
(\%)\end{array}$ & $\begin{array}{l}R_{\text {STEM }} \\
(\%)\end{array}$ & $\begin{array}{r}R_{\text {LEAF }} \\
(\%)\end{array}$ & Biome & Dominant species & Source \\
\hline $18.9 \pm 1.7$ & $33.0 \pm 4.5$ & $46.8 \pm 1.3$ & $20.2 \pm 2.7$ & Temperate & A. pseudoplatanus & This study \\
\hline $13.8 \pm 0.4$ & $80.9 \pm 0.2$ & $11.1 \pm 0.2$ & $8.0 \pm 0.1$ & Temperate & Populus tremuloides Michx., & $\begin{array}{l}\text { Calculated mean of 1999-2002 data } \\
\text { from Bolstad et al. (2004) }\end{array}$ \\
\hline $11.8 \pm 0.4$ & $75.4 \pm 0.4$ & $19.9 \pm 0.4$ & $4.8 \pm 0.1$ & Temperate & A. saccharum Marsh. & $\begin{array}{l}\text { Calculated mean of 1999-2002 data } \\
\text { from Bolstad et al. (2004) }\end{array}$ \\
\hline 9.61 & 73.2 & 11.8 & 15.1 & Boreal & P. tremuloides Michx., P. balsamifera L. & Griffis et al. (2004) \\
\hline $9.1 \pm 1.15$ & 67 & - & - & Temperate & Quercus robur, Pinus sylestris L. & Curiel Yuste et al. (2005b) \\
\hline
\end{tabular}

Conclusions

Tables

14

4

Back

Full Screen / Esc

Printer-friendly Version

Interactive Discussion 


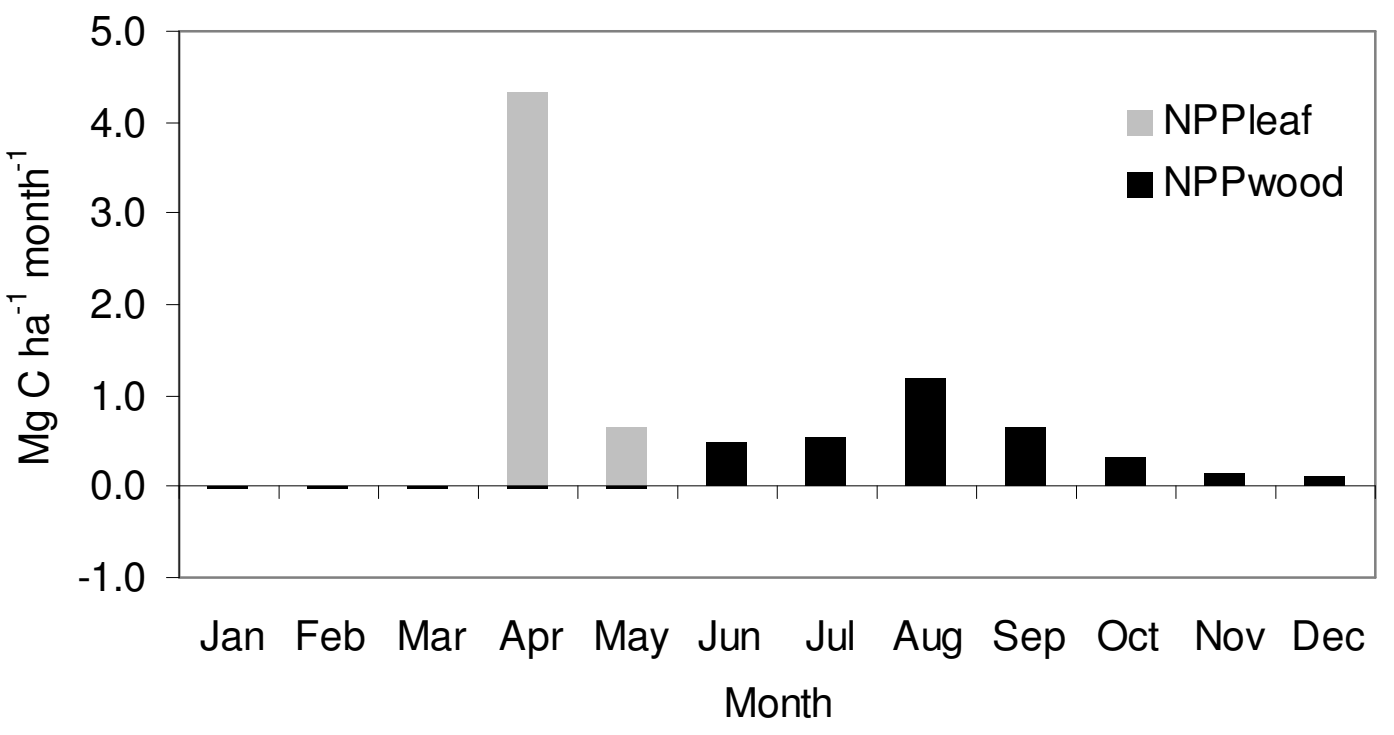

Fig. 1. Seasonality of leaf and wood production $\left(\mathrm{Mg} \mathrm{Cha}^{-1} \mathrm{month}^{-1}\right)$. Grey bars indicate leaf production, black bars indicate above-ground woody biomass production.
BGD

7, 3735-3763, 2010

\section{Temperate woodland} carbon cycle

K. Fenn et al.

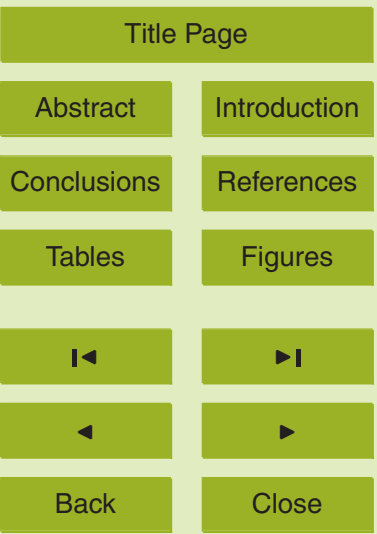

Full Screen / Esc

Printer-friendly Version

Interactive Discussion 


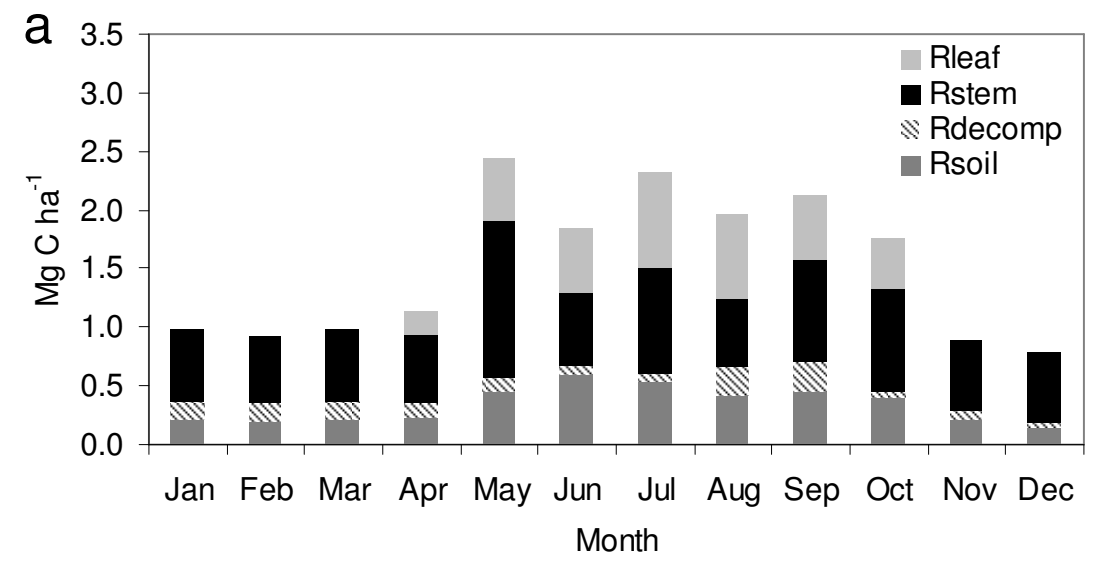

BGD

\section{7, 3735-3763, 2010}

\section{Temperate woodland carbon cycle}

\section{K. Fenn et al.}
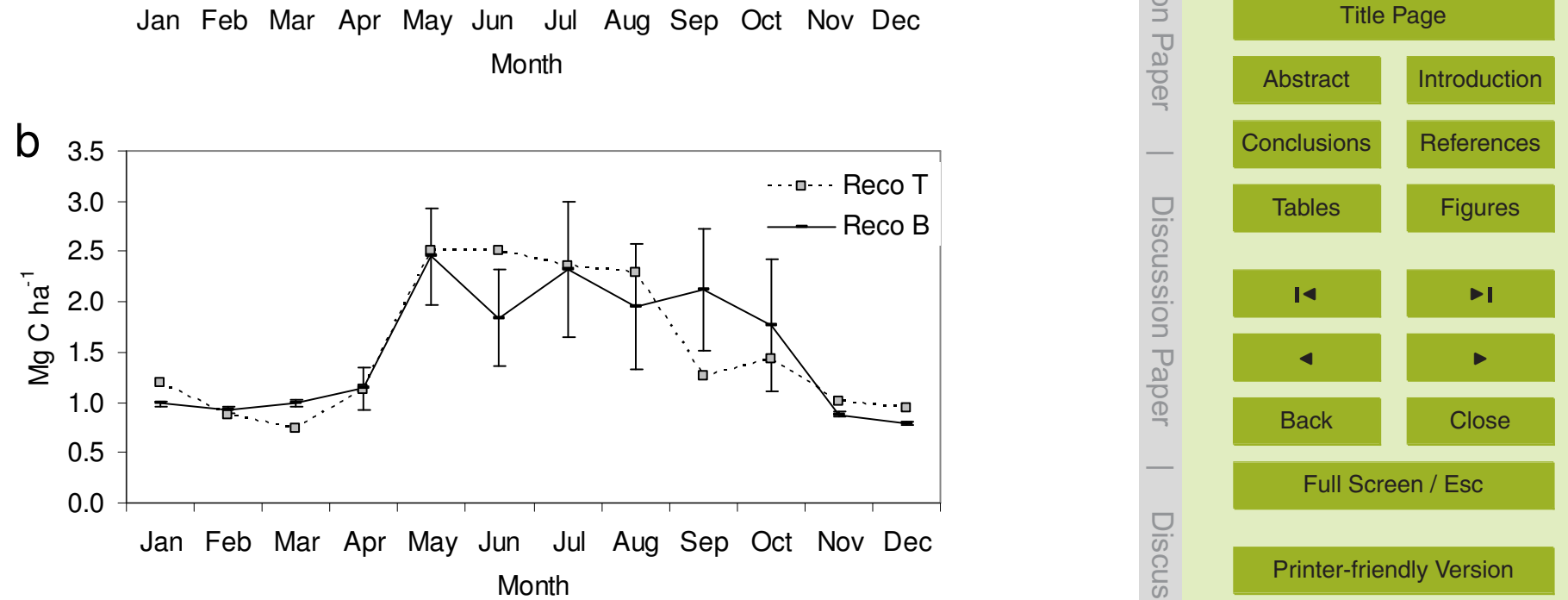

Introduction

Title Page

Printer-friendly Version

Fig. 2. (a) Contribution of each $R_{\mathrm{ECO}}$ component, per month, for 2008. (b) Comparison of biometrically calculated $2008 R_{\mathrm{ECO}}$ with that derived from eddy covariance estimates. $R_{\text {litter }}$ and $R_{\mathrm{CWD}}$ are not included as they cannot be estimated on a monthly basis. 


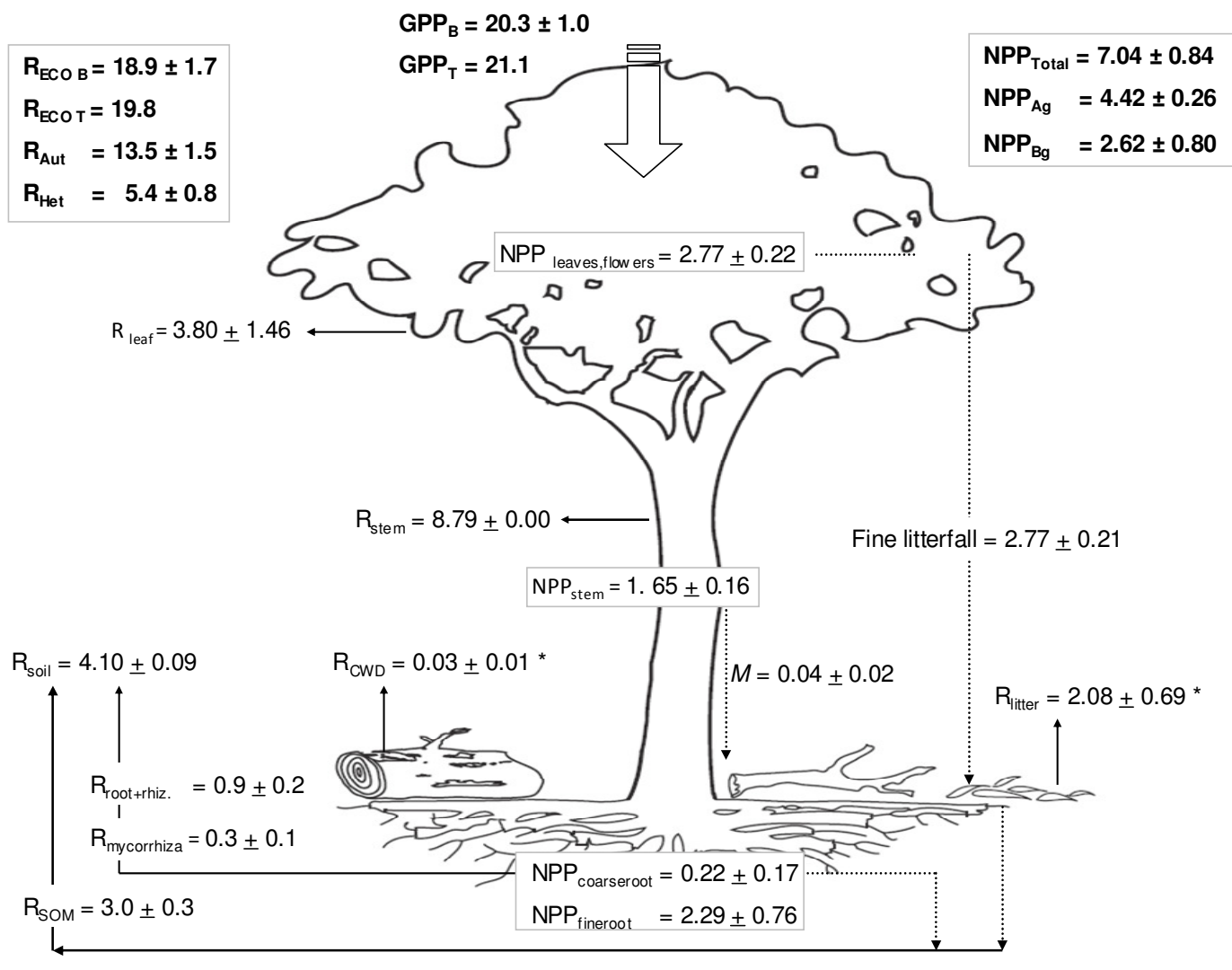

\section{BGD}

7, 3735-3763, 2010

\section{Temperate woodland} carbon cycle

\section{K. Fenn et al.}

\section{Title Page}

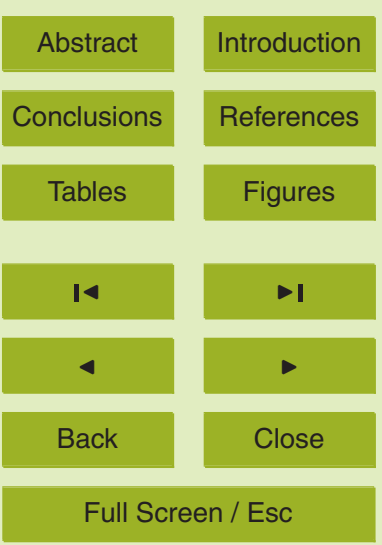

Fig. 3. Illustration of the carbon cycle of the site, constructed from the measured components. All soil respiration components are treated as heterotrophic respiration as root and rhizosphere contributions could not be separated. ${ }^{*}$ indicates components calculated using mass balance, rather than directly measured. 


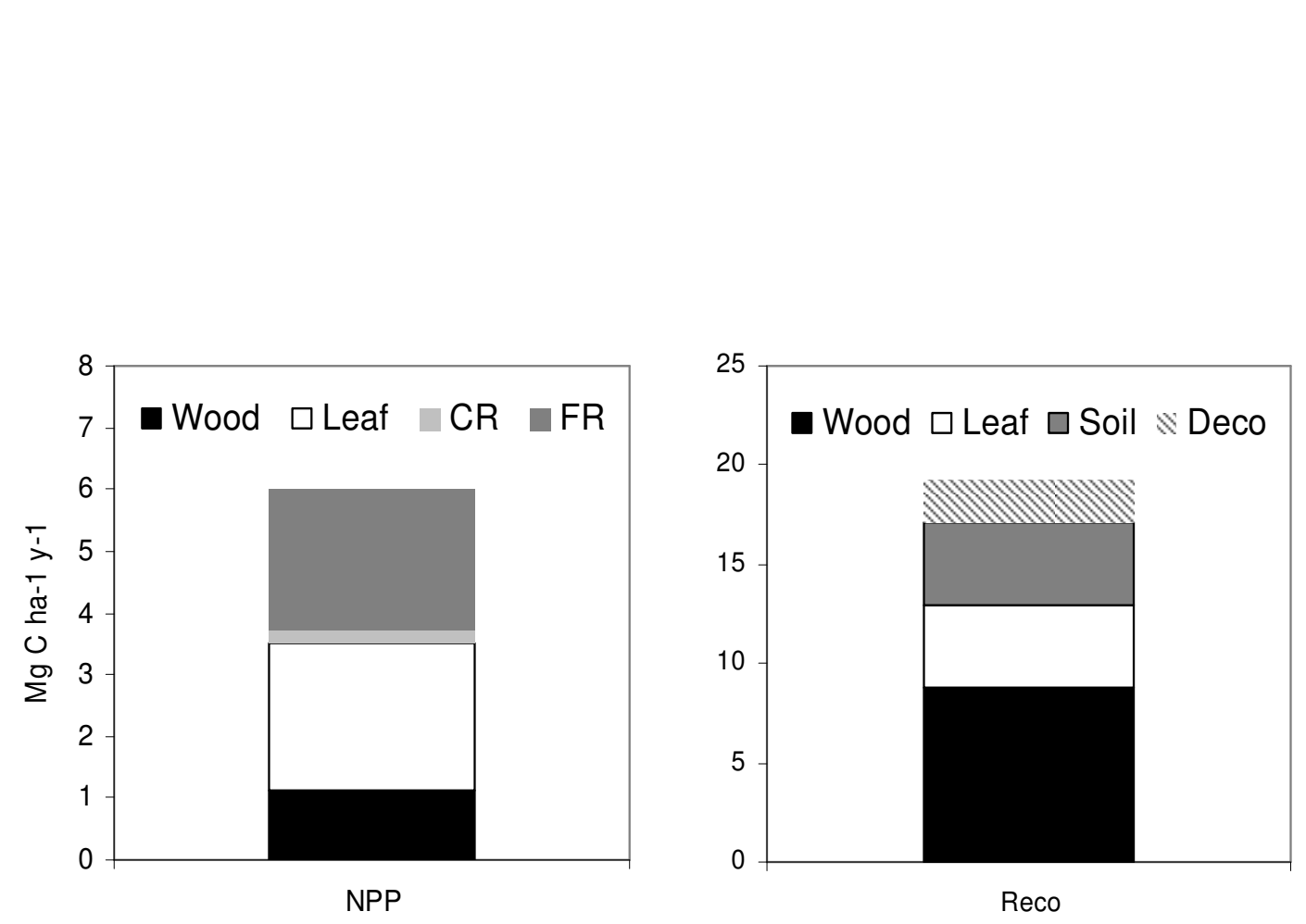

BGD

7, 3735-3763, 2010

Temperate woodland carbon cycle

K. Fenn et al.

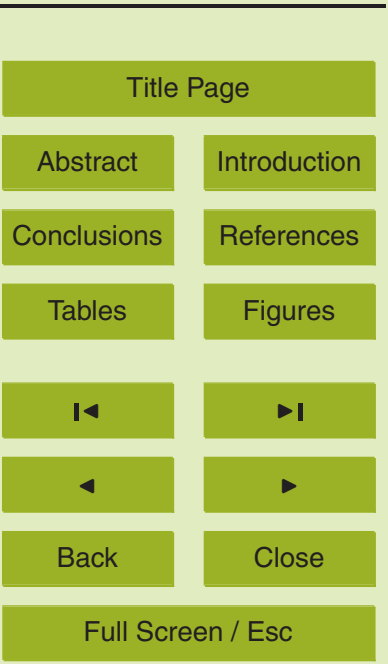

Printer-friendly Version

Interactive Discussion 